\title{
Integrating Local Community Perception and Expert's Knowledge in Spatial Multi- Criteria Evaluation (SMCE) for Landfill Siting in Musanze Secondary City
}

\author{
Ngwijabagabo, H. $^{1 *}$, Nyandwi, E. ${ }^{2}$, Barifashe, T. $^{1}$ \\ 1. Department of Geography and urban planning, University of Rwanda, College of Sciences and \\ Technology, P.O. Box: 3900 Kigali Rwanda \\ 2. University of Rwanda, College of Sciences and Technology, Centre for Geographic Information \\ Systems and Remote Sensing (CGIS - UR), P.O. Box: 3900 Kigali, Rwanda
}

*Correspondence: Hyacinthe Ngwijabagabo, Email: ngwijabagabohyacinthe@gmail.com

\begin{abstract}
Illegal dumping and landfilling of solid waste is a thoughtful concern nowadays. Solid wastes are disposed in open dumping sites and there is a lack of effective selection of potential and suitable site (s) for landfill, due to the ignorance of all criteria to be integrated in process of decision making. The purpose of this research is to find the most suitable site(s) for the construction of modern landfills using spatial multi-criteria evaluation (SMCE) and addressing the existing gap in involving the local community in the process of siting. Seven criteria of siting were selected combining national and international guidelines for landfill siting criteria. Selected criteria thresholding and ranking decision were grounded on local community preferences. Suitable criteria proximity distances were assessed with a questionnaire survey and further weighted using Expert's knowledge depending upon their relative importance. Final spatial overlay analysis results showed that the majority of the total area $(98.31 \%)$ is classified as unsuitable, with $0.05 \%$ of the total area being less suitable, $1.21 \%$ moderately suitable and only $0.43 \%$ of the total area is most suitable. Only 2 sites were found to be qualified as the most suitable and have the capacity of serving at least 10 years. This study is a model for filling the gap of community consultation during the process of landfill siting. It is also a very supportive tool for decision-makers to reduce "Not in my backyard" (NIMBY) phenomenon of waste disposal as well as environmental problems associated with illegal dumping.
\end{abstract}

Keywords: Landfill Siting, Expert's knowledge, Local community preferences, Spatial Multi-Criteria Evaluation.

\section{Introduction}

Solid waste management system in developing countries has become a significant risk to the surrounding environment (Babalola and Busu, 2011). Hadjibiros et al. (2011), argued that the absence of solid waste management in developing countries incite important pollutions, as well as an upsurge in greenhouse gases release. Therefore, appropriate site(s) selection for modern landfill is essential to decrease environmental destruction as well as to avert harmful impact to public health. Geo-Information provides techniques and tools to generate input factors in site selection and spatial multi-criteria evaluation (SMCE) as an ideal approach to 
identifying the suitable landfill site (Mornya, 2010). However, during the process of landfill siting, crucial stakeholders consultation workshops, including the local community's representative, are often omitted, or given less importance (Higgs, 2006). Therefore, involving local people in the exercise of landfill siting is necessary to create a competent Solid Waste Management system with the least negative environmental and social impact (Khan et al. , 2018).

To increase spatially equitable decision and community confidence which reduce widely encountered "not in my backyard" (NIMBY) syndrome, all stakeholders including the local community and public opinion should be considered at all stages of the process (Allen et Al., 2003). Comprehensive waste management is one of the thoughtful and pressing environmental concerns that the urban areas in Rwanda are now facing (Uwineza, 2012). Rugiramanzi (2013), argued that waste are disposed in open dumping sites that are randomly selected (cheap or available land). In Rwanda studies on landfill siting using fully the approach of SMCE to find suitable landfill sites are not many so far. Only Rugiramanzi (2013) conducted a study on site (s) selection for landfill using multi-criteria evaluation (MCE) techniques. The study did not consider the community participation in the process and spatial dimension.

The public involvement is crucial for various reasons, such as in fine-tuning the number of key input factors, their threshold definition, and for guaranteeing the spatial equity and acceptability of selected site. Several criteria for landfill site are highlighted in Standards of Waste Disposal Site (Landfill) document of Rwanda Utilities Regulatory Agency (RURA, 2009), and in Practical Tools on Solid Waste Management elaborated by Rwanda Environmental Management Authority (REMA, 2010). However, those criteria are unnoticed in most of the existing waste disposal sites, the selection seems to be based on land availability. Thus, the local knowledge is hardly considered in judgments and ranking of different criteria.

The secondary city of Musanze produce 150 tons per day of wastes and only 12 tons of them are dumped at public dumping site located in Cyuve sector. Currently, the dumping site has exceeded its maximum capacity to accommodate waste. In addition, it is located near the residential area and different hydrogeological diagnoses in the volcanic region showed that the water table of the dumping site is 5 meters deep (Musanze District, 2013). As a rapidly growing city (World Bank Group, 2017), Musanze secondary city needs to, beforehand, well locate landfills to reduce negative environmental damage. This study integrated socioeconomic and bio-physical factors through community and expert knowledge for landfill site selection in Musanze Secondary City. The developed approach could also be used for other cities either in Rwanda or other countries.

\section{Materials and Methods}

\subsection{Study area}

Musanze District is in the Northern Province of Rwanda, it has 15 Sectors, 68 Cells, and 432 Villages. Musanze City is one of the five important or prioritized secondary cities in Rwanda 
(RDDP, 2013). The City of Musanze has a population of 99,387 inhabitants within 20,260 households (NISR, 2012). It is comprising of four (4) Sectors including Muhoza, Kimonyi, Cyuve, and Musanze. Figure 1 shows the location and administrative delineation making up Musanze City, as determined by District Land Use and Development Plan (DLUDP).

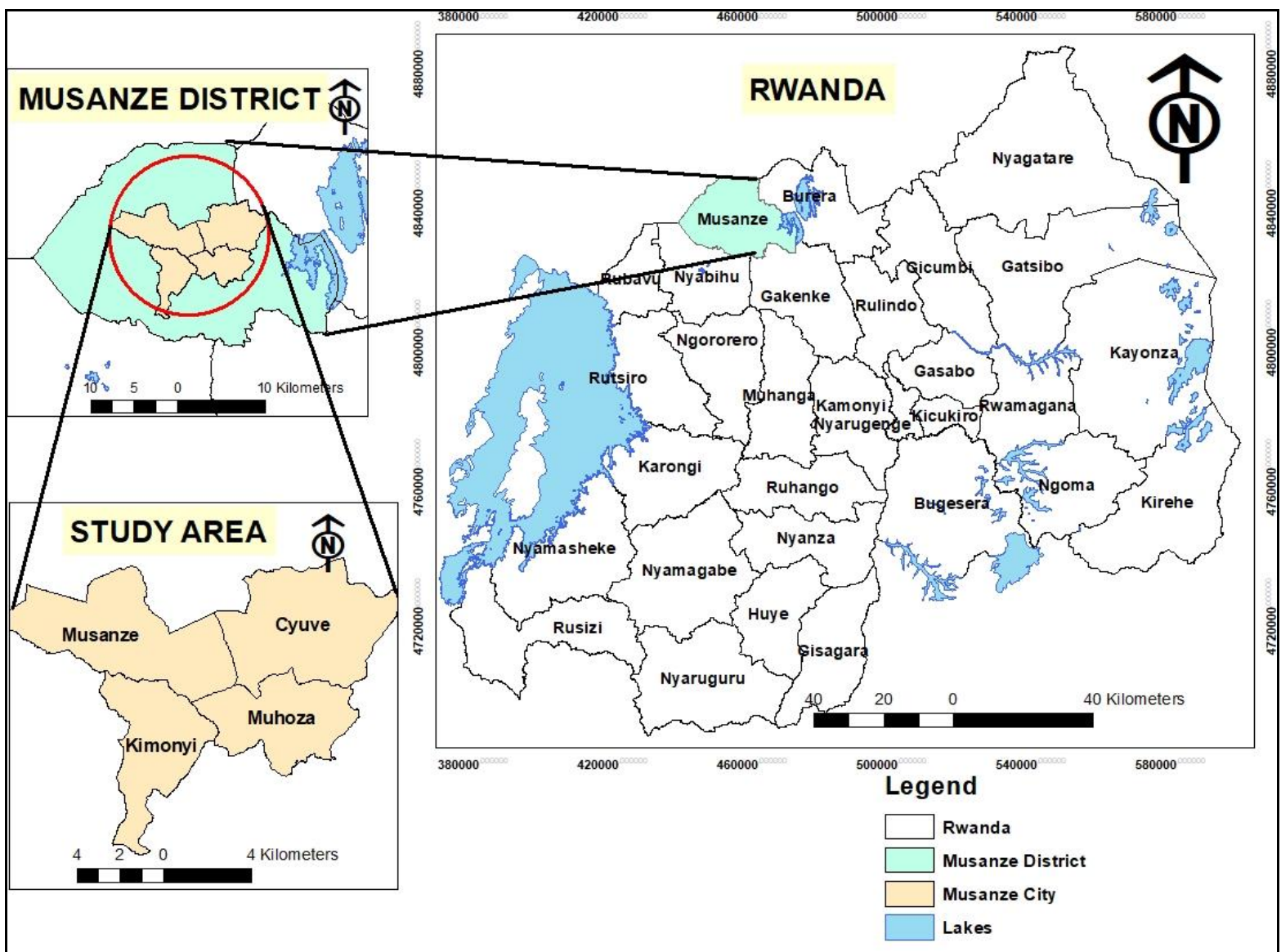

Figure 1: Location of Musanze District in Rwanda (Right) with Details of the Study Area (Lower Left)

Musanze secondary City is in the volcanoes region, at approximately $110 \mathrm{Km}$ from Kigali. The city is densely populated with 99,387 inhabitants and surrounded by relatively developed agriculture (NISR, 2012). But, the city is speedily developing mainly due to the booming activities related to the tourism industry (MININFRA, 2016). Therefore, the city needs to be forehanded a suitable located sanitary landfill as more business activities and an increasing population will generate a considerable amount of waste in the future.

\subsection{Input data identification and collection}

Seven criteria were identified from a set of REMA and RURA regulations and other studies documenting landfill selection criteria. Those criteria are distance to surface water, wetland, floodplain, soil texture, slope, residential area, and major roads.

Surface Water: Landfill must be located away from surface water to reduce health risks associated to the contaminated surface water. The ultimate distance from surface water varies from authors, Rwanda Environmental Management Authority proposed 300m (REMA, 
2010); 1000m according to Mornya (2010) and 500m are suggested by Nwambuonwo \& Mughele (2012).

Wetland/Peat Borg/Swamp: To minimize the effect of landfill leachate Yazdani et al. (2017) proposes a buffer ranging between 500m and1000m while Ouma, Kipkorir, \& Tateishi (2011) proposed $2000 \mathrm{~m}$ of the buffer.

Residential Area: The residential area is an important criterion in landfill siting as it reduces the issue of 'not in my backyard', known to be expressed by the local community in protestation against the siting of landfill facility close to their residential (Ahmad et al., 2014). Different distances from residential areas are also proposed by different authors to avoid bad smell from waste: 250m by REMA (2010); 400m by RURA (2009) and $500 \mathrm{~m}$ are suggested by the World Bank Group (2010).

Major Roads: REMA and RURA were quit at this point, while the distance from major roads is an important socio-economic criterion in landfill siting (Gbanie et al., 2013). The landfill located too close to the major road is regarded as a limitation to the development of touristic economic activities of the city (RDDP, 2013). Ahmad et al. (2014), proposed buffer ranging between $100 \mathrm{~m}-3000 \mathrm{~m}$ and argued that a landfill must be easily accessible by the waste collection vehicles to reduce the cost for the road construction.

Flood Plain: It is restricted to locate a landfill in the floodplain zone (REMA, 2010). A buffer zone of $100 \mathrm{~m}$ from the floodplain area must be respected as proposed by Korucu et al. (2013).

Soil Permeability: low permeability of soil should be considered to retain pollutants before reaching and polluting the groundwater. Therefore, an area with a high percentage of clay is preferred as it has low permeability (Mornya, 2010).

Slope: REMA (2010) proposed a gently sloped topography of about 2\%. Kirimi and Waithaka (2014) suggested that a slope of less than $12 \%$ would be suitable for the prevention of contaminant runoff. Allen et al., (2003), considered $10 \%$ as maximum and less is the most suitable slope for landfill siting. According to the expertise view of different authors, a gentle and moderate slope $(2-12 \%)$ is preferred while locating a landfill.

We didn't consider the criteria of protected areas such as Volcanoes National parks, because it is relatively far from our study area (more than $10 \mathrm{~km}$ ). Other important landfill siting criterions such as business, recreational, and religious and cultural sites were combined with a residential area since business area and residential areas are found to be mixed in our study area.

The identified criteria maps (GIS Layers) were gathered from different sources as summarized in Table 1. 
Table 1: Used Spatial Data and their Respective Sources

\begin{tabular}{|c|c|c|}
\hline No & Layers & $\begin{array}{l}\text { Description (Source, spatial and temporal resolution, } \\
\text { limitations and/or assumptions) }\end{array}$ \\
\hline 1 & $\begin{array}{l}\text { Administrative } \\
\text { boundary (from } \\
\text { district to } \\
\text { villages) }\end{array}$ & $\begin{array}{l}\text { Administrative boundary layers created in } 2006 \text { by MINALOC, } \\
\text { further adjusted/updated by NISR in } 2012 \text { in the process of census } \\
\text { mapping, where a team of } 80 \text { field staff collected census and } \\
\text { administrative boundaries up to the lowest administrative level } \\
\text { which is "Umudugudu". Boundaries were adjusted in the GIS lab } \\
\text { using the 2008-2009 Orthophotos taken by the Rwanda Natural } \\
\text { Resource Authority. }\end{array}$ \\
\hline 2 & Surface water & \multirow{3}{*}{$\begin{array}{l}\text { River, streams, and waterbodies layers were provided by District } \\
\text { One-stop Centre. The database is a result of the } 2008 \text { mapping by } \\
\text { REMA cross-validated by district one-stop GIS Officer. }\end{array}$} \\
\hline 3 & Wetlands & \\
\hline 4 & Flood plain & \\
\hline 5 & & $\begin{array}{l}\text { One attribute of Rwanda soil map layer of MINAGRI, reviewed by } \\
\text { Water for Growth project of Ministry of Environment (Water and } \\
\text { Forestry Authority) }\end{array}$ \\
\hline 6 & $\begin{array}{l}\text { DEM } 10 \mathrm{~m} \\
* 10 \mathrm{~m} \text { resolution }\end{array}$ & $\begin{array}{l}\text { Created by Land Authority in 2008-2009 during the process of } \\
\text { ortho-photographs generation by the former Rwanda Natural } \\
\text { Resources Authority (currently, Rwanda Land Management and } \\
\text { Use Authority). }\end{array}$ \\
\hline 7 & $\begin{array}{l}\text { Residential } \\
\text { Area }\end{array}$ & $\begin{array}{l}\text { Build up areas and their defined uses by Rwanda Housing } \\
\text { Authority, } 2015\end{array}$ \\
\hline 8 & Major Roads & $\begin{array}{l}\text { Road network as digitalized from topographic map of } 1988 \text { and } \\
\text { further corrected updated and classified by Rwanda Transport } \\
\text { Development Authority (RTDA) in } 2018\end{array}$ \\
\hline
\end{tabular}

\subsection{Sampling and Collection of Stakeholders' Information}

The identified criteria were ranked referring to the local community preferences to bridge the existing gap of lack of local community perceptive and promote public confidence. Data on community preferences regarding criteria were collected using GIS collector. The questionnaire was designed in GIS collector, face to face interview was used to complete the questionnaire depending upon the level of literacy of the respondent. Considering the total number of 34930 households $(\mathrm{HH})$ of Musanze city, using the following Yamane's formula with a confidence level of $90 \%$ or $\boldsymbol{\alpha}=\mathbf{0 . 1 0}$ we come up with $100 \mathrm{HH}$ to survey.

$$
n=\frac{N}{1+N(\alpha)^{\wedge} 2}
$$


Where $\mathrm{n}$ is the sample size; $\mathrm{N}$ is the number of households in Musanze city, and $\alpha$ is confidence level. The sample size was: 34930/1+34930(0.01) = 99.7 100 households (hhs), and they were sampled randomly, and a household representative from each sample household was interviewed. The interview guiding questions were designed to allow this study to come up with the level of landfill siting preference by local communities of distances categorized as follow, regarding:

1. Wetland: (a)0-500m; (b)500m-1000m; (c)1000m-2000m; (d) >2000

2. Surface water: (a)0m-300m;(b)300m-500m, ;(c)500m-1000m; (d) >1000m

3. Residential Area: (a)0m-250m;(b) 250m-400m;(c) 400m-500m;(d) > 500m

4. Major Roads: (a)0m-100m; (b) 100m-500m; (c) 500m-3000m;(d) > 3000m

\subsection{Used Software}

Different software and the latest applications were used for this study. The most important were: Collector for Arc GIS part of Esri Geospatial cloud and a mobile collection application that can be downloaded using Appstore and it facilitates field workers in data collection with accuracy. Considering our case, a free trial of the version that lasts 21 days was used in household Survey of the community preferences on criteria; Super Decision Software a freely available decision-making software that is used in multicriteria decision making, the software computes designed decision models using super matrices of the Analytic Network Process (Adams \& Saaty, 2003). In our case, the Super Decision software environment was used to process the comparison and determine the weight of biophysical and social-economic criteria based on the expert's knowledge and ArcGIS 10.4 software, powerful software that is used to create, manage, analyse and share geographic information. In our case, Arc GIS software was used to create criterion maps and suitability maps. Prepared layers were evaluated in the GIS platform and maps of criteria were produced. Processes of overlaying and suitability analysis of maps were performed to identify the most suitable site for a landfill. Query Builder tool was used to select only the potential landfill sites that have at least 1 ha from the entire eligible areas.

\subsection{Criteria Ranking and Weighting}

Criteria were ranked as 1,2 , and 3 referring to the classification opinion; where 0 : Unsuitable, 1: less suitable, 2: moderate suitable, and 3: most Suitable. Regarding the local community preferences residential area criteria, surface water criteria, major road criteria, and wetland criteria were ranked (Figure2). 


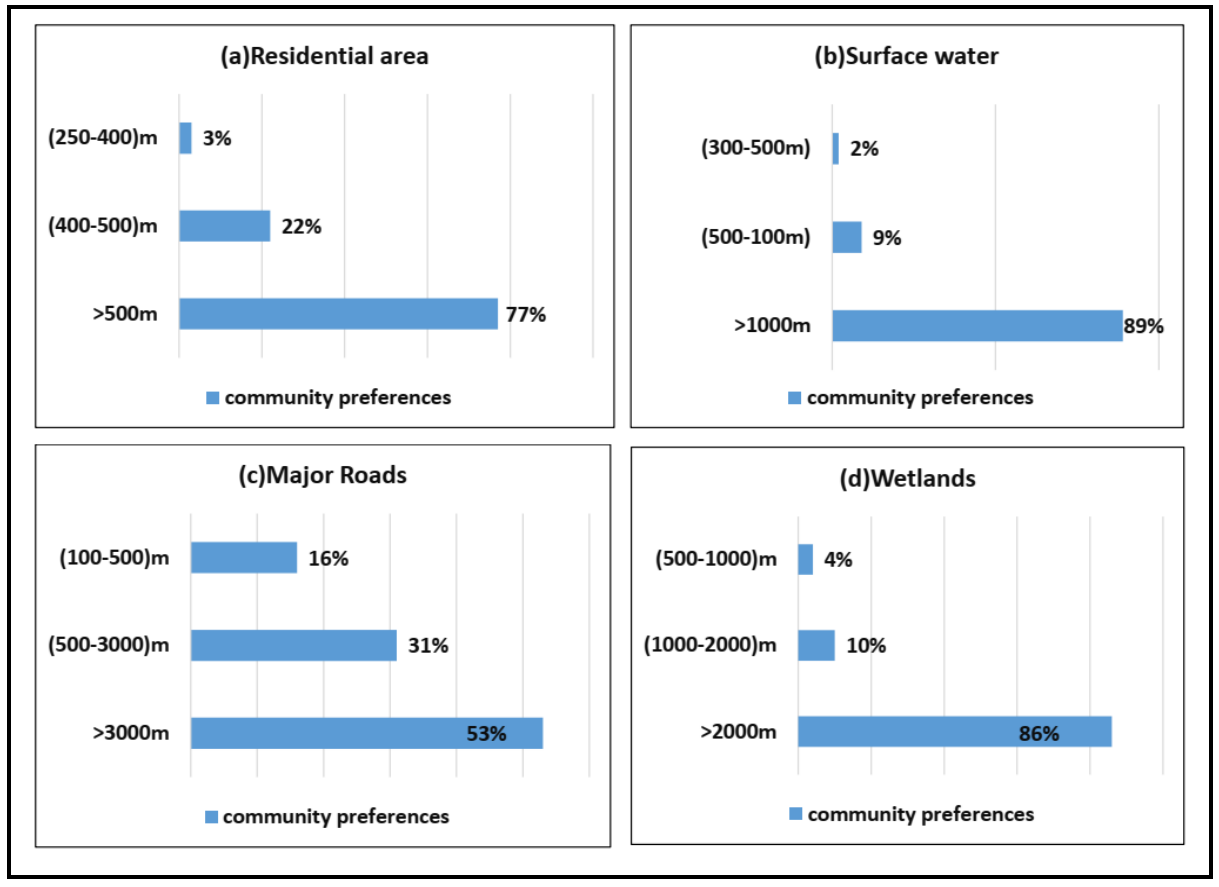

Figure 2: Community Preferences for Landfill Siting

The thresholds of physical factors (Slope, Soil permeability, and floodplain) in those three classes were decided using expert knowledge after confronting what was proposed by different authors (under previous paragraph 2.2.), different stakeholders, and observations on field.

Criteria weighting was performed in Super Decision software using pairwise comparison. According to Al-anbari et al. (2018), criteria weighting is the level of importance given to the criterion that designates relative significance to other criteria in consideration. Criteria weighting assist in decreasing bias and conflict that may arise in the presence of multiple criteria during the exercise of landfill siting (Abdullah et al., 2011). The method consists of comparing the relative importance of the two criteria (Saaty, 2006). The scale for pairwise comparisons ranging from 1 to 9 proposed was filled in Super Decision software, using importance intensity generated referring to Musanze District in charge of environment, forestry, and natural resources expert opinion. After the completion of the pairwise comparison matrix in super decision software, the consistency in pairwise was verified, as suggested by (Ebistu and Minale, 2013) the values in the matrix need to be consistent and the rule is that the consistency ratio must be less than or equal to 0.10 and If we found that $\mathrm{CR} \geq$ 0.10 , the values of the ratio indicates inconsistent judgments. In the case of this study $\mathrm{CR}=$ 0.09 which is less than 0.10 . Hence we concluded that the weights which was given by the District expert were more reasonable. Local community ranking of criteria and expert judgment on weighting are summarized in table 2 : 
Table 2: Results of Ranking and Weighting of Criteria

\begin{tabular}{|c|c|c|c|c|}
\hline Factors & Criteria & Parameters & $\begin{array}{l}\text { Ranking (based on } \\
\text { community } \\
\text { preferences) } \\
\text { 0: Unsuitable } \\
\text { 1: Less suitable, } \\
\text { 2: Moderate suitable, } \\
\text { 3:Most suitable }\end{array}$ & $\begin{array}{l}\text { Weight }(\%) \text { based } \\
\text { on expert } \\
\text { judgments }\end{array}$ \\
\hline \multirow{16}{*}{$\begin{array}{l}\text { Bio- } \\
\text { physical } \\
(\mathrm{BP})\end{array}$} & \multirow{4}{*}{ Wetland } & $>2000 \mathrm{~m}$ & 3 & \multirow{4}{*}{$11 \%$} \\
\hline & & $1000 \mathrm{~m}-2000 \mathrm{~m}$ & 2 & \\
\hline & & $500 \mathrm{~m}-1000 \mathrm{~m}$ & 1 & \\
\hline & & $0 \mathrm{~m}-500 \mathrm{~m}$ & 0 & \\
\hline & \multirow{4}{*}{$\begin{array}{l}\text { Surface } \\
\text { water }\end{array}$} & $>1000 \mathrm{~m}$ & 3 & \multirow{4}{*}{$11 \%$} \\
\hline & & $500 \mathrm{~m}-1000 \mathrm{~m}$ & 2 & \\
\hline & & $300 \mathrm{~m}-500 \mathrm{~m}$ & 1 & \\
\hline & & $0 \mathrm{~m}-300 \mathrm{~m}$ & 0 & \\
\hline & \multirow{3}{*}{$\begin{array}{l}\text { Flood } \\
\text { plain }\end{array}$} & $>100 \mathrm{~m}$ & 3 & \multirow{3}{*}{$9 \%$} \\
\hline & & $0-100 \mathrm{~m}$ & 1 & \\
\hline & & $0 \mathrm{~m}$ & 0 & \\
\hline & \multirow{2}{*}{$\begin{array}{l}\text { Soil } \\
\text { permeabil } \\
\text { ity }\end{array}$} & $\%$ of Clay $<35$ & 0 & \multirow[b]{2}{*}{$8 \%$} \\
\hline & & \%of Clay>35 & 3 & \\
\hline & \multirow{3}{*}{ Slope } & $1-2 \%$ & 3 & \multirow{3}{*}{$2 \%$} \\
\hline & & $2 \%-10 \%$ & 2 & \\
\hline & & $12 \%<$ & 1 & \\
\hline \multirow{8}{*}{$\begin{array}{l}\text { Socio- } \\
\text { Economic } \\
(\mathrm{SE})\end{array}$} & \multirow{4}{*}{$\begin{array}{l}\text { Residenti } \\
\text { al Area }\end{array}$} & $>500 \mathrm{~m}$ & 3 & \multirow{4}{*}{$57 \%$} \\
\hline & & $400 \mathrm{~m}-500 \mathrm{~m}$ & 2 & \\
\hline & & $250 m-400 m$ & 1 & \\
\hline & & $0 \mathrm{~m}-250 \mathrm{~m}$ & 0 & \\
\hline & \multirow{4}{*}{$\begin{array}{l}\text { Major } \\
\text { Roads }\end{array}$} & $>3000 \mathrm{~m}$ & 3 & \multirow{4}{*}{$2 \%$} \\
\hline & & $500 m-3000 m$ & 2 & \\
\hline & & $100 \mathrm{~m}-500 \mathrm{~m}$ & 1 & \\
\hline & & $0 \mathrm{~m}-100 \mathrm{~m}$ & 0 & \\
\hline
\end{tabular}

\section{Results and Discussions}

\subsection{Selected, Ranked and Weighted Criteria using an Integrated SMCE}

Considering people's preference for Biophysical and socio-economic factors the results showed that people prefer landfill infrastructure away from their natural environment (surface and groundwater, wetland/marshland) and also far away from their socio-economic activities such as residential, settlements and other commercial activities.

As illustrated by Figure 3; map in Figure 3a shows that most of the community prefer landfill facility away from their residential area. This is also supported by (Nas et al., 2010), that 
suggested that a landfill should be kept as far as possible away from population density to reduce pollution impact on public health. Figure $3 \mathrm{~b}$ shows that the majority of the local community of Musanze city prefer landfill facility far away $(1 \mathrm{~km})$ to the existing surface water. The choice of the local community is backed in (Mornya et al., 2010), who argued that locating landfill close to water may have an irrevocable environmental and health impact. Map in Figure 3c shows that the local community of Musanze District prefers landfill facility at $3000 \mathrm{~m}$ and above away to the major roads. This is also supported with (RDDP, 2013), which argued that locating landfill adjacent to socio-economic activities is a limitation to the development of touristic economic activities of the city. Musanze city is considered as the staging point for their tourism activities and tourists visiting Volcanoes National Park stay in its hotels and guesthouses, patronize its restaurants (Musanze District, 2013). Therefore, locating landfill close to major roads is a limitation to the development of touristic economic activities of Musanze city. Map in Figure 3d, visualise community preferences on wetland proximity to landfills. Most of the local community proposed $2000 \mathrm{~m}$ and above as the most suitable proximity to locate wetland. That local community choice is also supported in (Yazdani et al., 2015), where the author proposed that landfills should not be close in wetland and humid areas due to the vulnerability and sensitivity of their special bio-physical conditionals. 


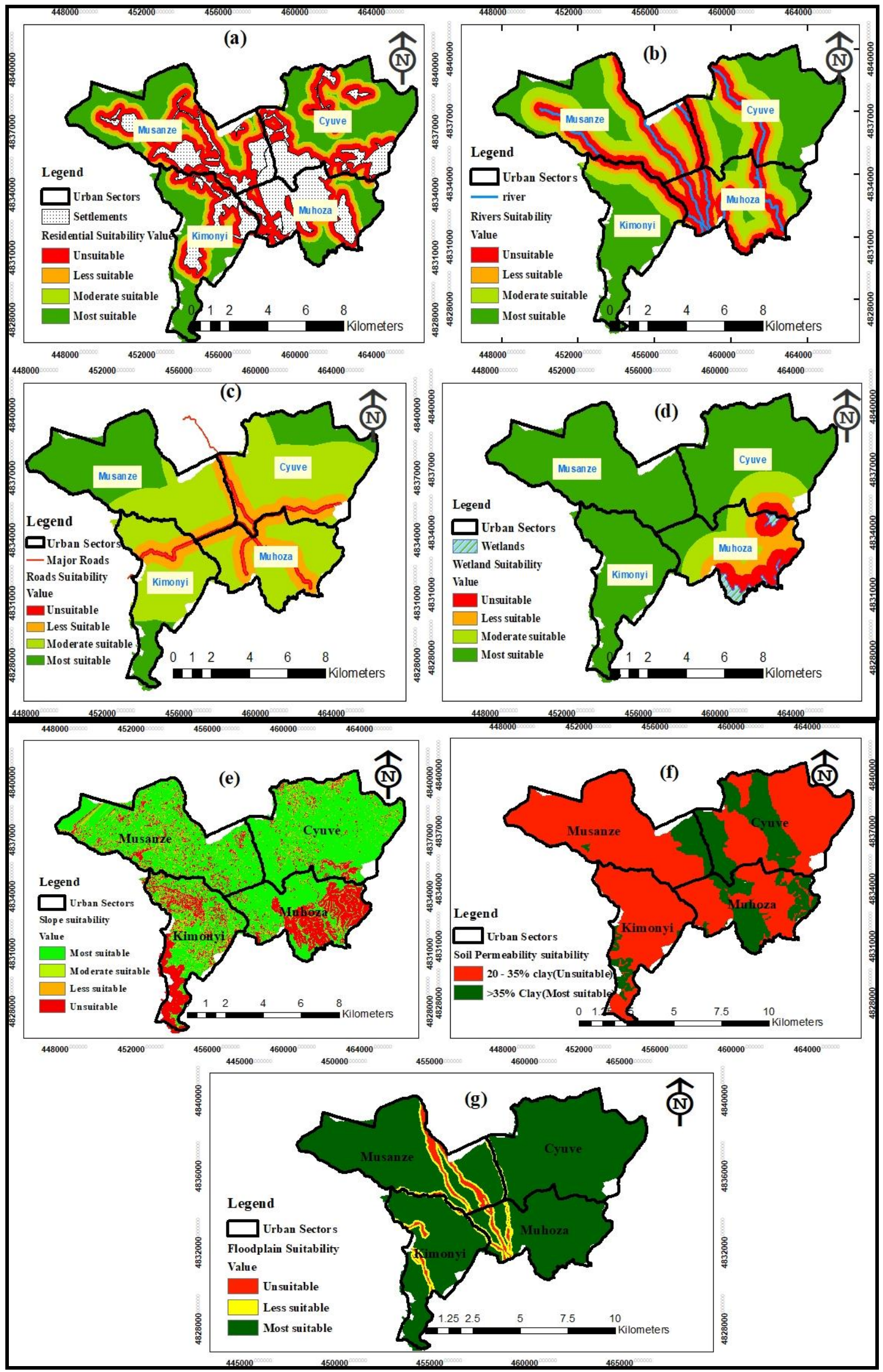

Figure 3: SMCE Suitability Maps Based on Expert's Knowledge and Community Perception 


\subsection{Landfill Sites Location Suitability Map}

As illustrated by maps in Figure $4 a \& 4 b$, the result of the spatial overlay of factors maps showed that the total area of the urban area covers approximately 10,602.08 ha and unsuitable area covered about 10423.26 ha of the total area, less suitable area covers 5.53 ha, moderate suitable area covers 1.21 ha and most suitable covers 45.35ha of the total area. Basing on the classification of the map (Figure 4a), about 156 sites are most suitable to locate a landfill. However as illustrated by the map in Figure 4b, among those most suitable sites only 2 sites have 1 ha and above and are therefore capable of serving the city at least in a 10year period, as suggested in Adefris (2015) that a site should be capable of serving at least for a period of 10 years, in order to reduce costs for site identification, establishment, operation, and closing. Those 2 sites selected are all located in the Cyuve sector and are not far from the city center. The selected sites are in different cells, one in Migeshi cell with 30.5ha and the other one located in Buruba cell with 14.85ha. According to the study of the Government of Rwanda and GGGI (2015), solid waste in Musanze City was projected to 50,600 tons per year in 2020 and 39.9 ha was found to be the area required for landfill construction. The identified sites have in total 45.35 ha that are the most suitable area for landfill construction. Sites selected were checked using the 2019 google earth image, the site that has 14.85 ha located in Buruba cell was found to be near a residential area, therefore landfill construction would require the expropriation of some houses and this could also create not in my backyard issue. The site that has 30.5 ha located in Migeshi cell was found to be the most favorable in landfill siting because it is far away from the residential area and has more space required compared to the estimation of 39.9 ha proposed. 


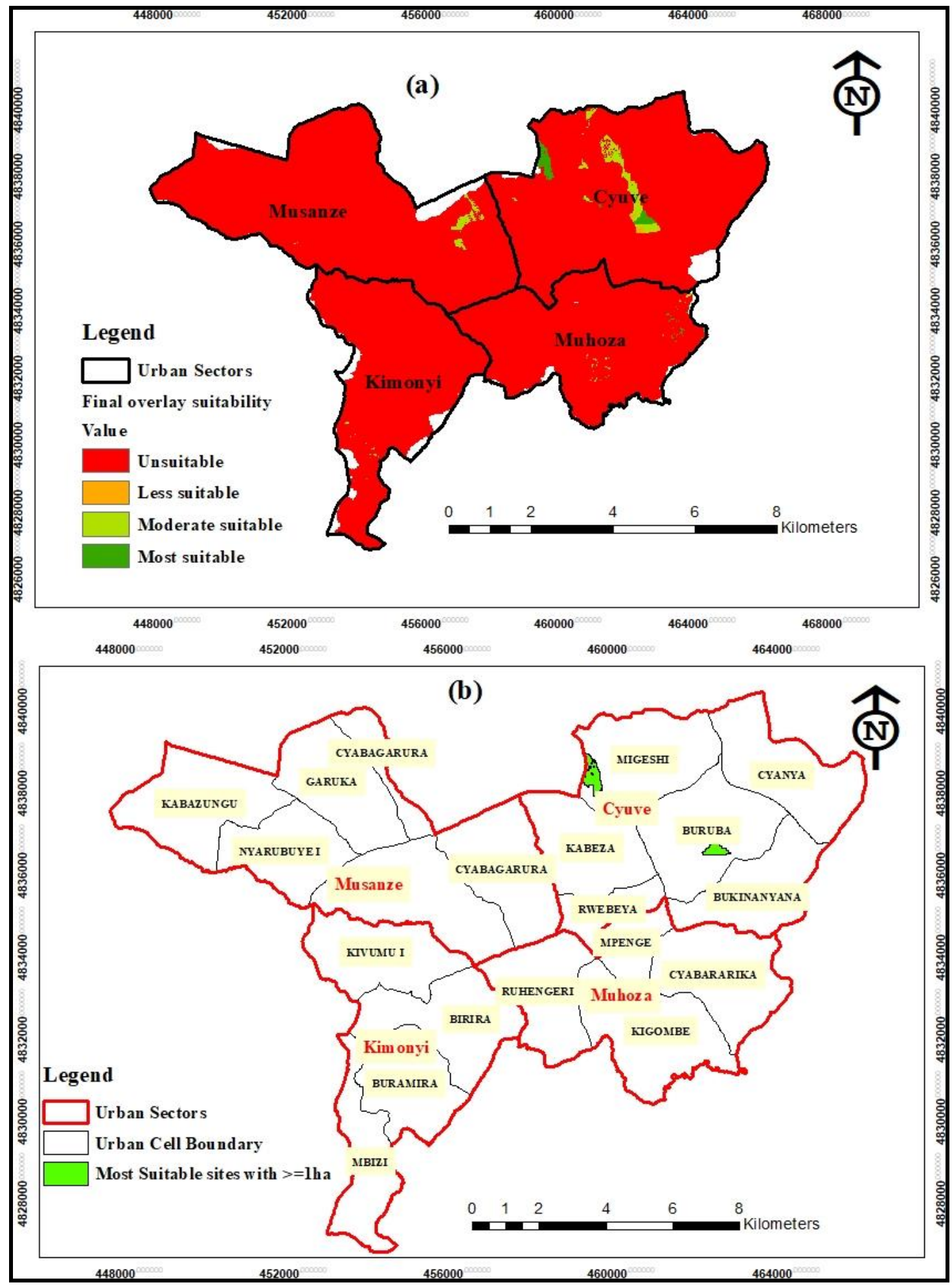

Figure 4: Final Maps of SMCE based on Expert's Knowledge and Community Perception 


\section{Conclusions and Recommendations}

An integrated SMCE of landfill sites, using different pieces of literature and national and international standards seven criteria were identified (Surface water, wetland, floodplain, soil texture, slope, residential area, and major Roads) and standardized in three classes of Unsuitable, less suitable, moderately suitable and most suitable. Those classes had been finetuned, ranked, and weighted using local community perception and expert knowledge. Thus, the acceptable distance from a residential area was the most important criterion, while major roads and slope were given the lowest weight of importance. Our approach had inner crossvalidation which comes up with a final suitability map demarcating only two most suitable sites. However, due to the abnormal structure of bedrocks from a tectonic movement that generated volcanic soil in our study area, a detailed geotechnical study of the areas is recommended to apprehend efficiently the issue of groundwater and its potential pollution. This study is a model for reducing the existing gap of community consultation during the process of landfill siting, and it can be replicated in Kigali city and other secondary cities of Rwanda if effective stakeholder consultation and expert knowledge are combined. In addition, regarding the existing gaps in the landfill siting process, we recommend (i) a systematic combination in SMCE of the local community and expert's knowledge; (ii) an imperative field visit for the ground-truthing of the potentially identified site(s), in order to choose a site that minimises negative impacts and conflicts with other land uses and (iii) a detailed Environmental Impact Assessment (EIA) to be done specifically on most suitable site(s) identified using GIS and SMCE instead of considering site identified based on land availability only.

\section{References}

Abdullah, L., Naim, N. S., \& Wahab, A. F. (2011). Determination of weight for landfill-siting criteria under conflicting bifuzzy preference relation. Journal of Sustainability Science and Management, 6(1), 139-147.

Adams, W., \& Saaty, R. (2003). Super Decisions Software Guide. Super Decisions. http://www.ii.spb.ru/admin/docs/SuperDecisionsHelp2011.pdf

Adefris, A. (2015). Evaluation of solid waste landfill potential site using GIS-based MultiCriteria Evaluation Method: a case study of ADDIS ABABA.

Ahmad, S. Z., Ahamad, M. S. S., \& Yusoff, M. S. (2014). Spatial effect of new municipal solid waste landfill siting using different guidelines. Waste Management and Research, 32(1), 24-33. https://doi.org/10.1177/0734242X13507313

Al-anbari, M. A., Thameer, M. Y., \& Al-ansari, N. (2018). Landfill Site Selection by Weighted Overlay Technique: Case Study of Al-Kufa, Iraq. 1-11. https://doi.org/10.3390/su10040999

Allen, A., Brito, G., Caetano, P., Costa, C., Cummins, V., Donnelly, J., Koukoulas, S., 
O’Donnell, V., Robalo, C., \& Vendas, D. (2003). A Landfill Site Selection Process Incorporating GIS Modelling. Proceedings Sardinia 2003, Ninth International Waste Management and Landfill Symposium, October 2003, 1-11.

Babalola, A., \& Busu, I. (2011). Selection of Landfill Sites for Solid Waste Treatment in Damaturu Town-Using GIS Techniques. Journal of Environmental Protection, 02(01), 1-10. https://doi.org/10.4236/jep.2011.21001

Ebistu, T. A., \& Minale, A. S. (2013). Solid waste dumping site suitability analysis using geographic information system (GIS) and remote sensing for Bahir Dar Town, North Western Ethiopia. African Journal of Environmental Science and Technology, 7(11), 976-989. https://doi.org/10.5897/AJEST2013.1589

Gbanie, S. P., Tengbe, P. B., Momoh, J. S., Medo, J., \& Kabba, V. T. S. (2013). Modelling landfill location using Geographic Information Systems (GIS) and Multi-Criteria Decision Analysis (MCDA): Case study Bo, Southern Sierra Leone. Applied Geography, 36(May 2016), 3-12. https://doi.org/10.1016/j.apgeog.2012.06.013

Government of Rwanda and GGGI. (2015). Republic of Rwanda National Roadmap for Green Secondary City Development National Roadmap for Green Secondary City Development.

Hadjibiros, K., Dermatas, D., Laspidou, C. S., \& Areos, P. (2011). Municipal Solid Waste Management and Landfill Site Selection in GREECE: IRRATIONALITY VERSUS EFFICIENCY. 13(2), 150-161.

Khan, D., Kumar, A., \& Samadder, S. R. (2018). Public acceptance study of environmentally suitable landfill sites. Current Science, 115(11), 2122-2129. https://doi.org/10.18520/cs/v115/i11/2122-2129

Kirimi, F. K., \& Waithaka, E. H. (2014). Determination of Suitable Landfill Site Using Geospatial Techniques and Multi-Criteria Decision Analysis : A Case Study of Nakuru Town, Kenya. International Journal of Science and Research (IJSR), 3(11), 500-505.

Korucu, M. K., Arslan, O., \& Karademir, A. (2013). Siting a municipal solid waste disposal facility, Part one: An evaluation of different scenarios for a site selection procedure. Journal of the Air and Waste Management Association, 63(8), 879-885. https://doi.org/10.1080/10962247.2013.788459

MININFRA. (2016). Rehabilitation and Upgrading of Karere-Mpenge-Sonrise Road (Roads coded R24, R33A \& R42) Infrastructure of Musanze City in the District of Musanze Final Report. January.

Mornya, A. A. (2010). Identification of potential landfill sites by using GIS and multicriteria method in Batam, Indonesia. 3rd International Graduate Conference on Engineering, Science, and Humanities, November. 
Mornya, A. A., Yola, L., \& Rafee, M. (2010). Identification of Landfill Sites by Using GIS and Multi-Criteria Method in Batam , Indonesia. International Graduate Conference on Engineering Siences and Humanities, March 2010. https://www.academia.edu/545126 on 02 July, 2019

Musanze_District. (2013). Sanitation Master Plan for Musanze Town. January 2012, 239. https://doi.org/10.1190/segam2013-0137.1

Nas, B., Cay, T., Iscan, F., \& Berktay, A. (2010). Selection of MSW landfill site for Konya, Turkey using GIS and multi-criteria evaluation. Environmental Monitoring and Assessment, 160(1-4), 491-500. https://doi.org/10.1007/s10661-008-0713-8

NISR. (2012). 2012 Population and Housing Census. November.

Nwambuonwo, O. J., \& Mughele, E. S. (2012). Using Geographic Information System to Select Suitable Landfill Sites For Megacities (Case Study of Lagos, Nigeria). Computing, Information Systems \& Development Informatics, 3(4), 48-57.

Ouma, Y. O., Kipkorir, E. C., \& Tateishi, R. (2011). MCDA-GIS integrated approach for optimized landfill site selection for growing urban regions: An application of neighborhood-proximity analysis. Annals of GIS, 17(1), 43-62. https://doi.org/10.1080/19475683.2011.558021

RDDP. (2013). District Development Plan. July, 237. http://www.bugesera.gov.rw/fileadmin/user_upload/Bugesera_District_DDP_201217_Final.pdf

REMA. (2010). Practical Tools on Solid Waste Management of Imidugudu, Small Towns and Cities : Landfill and Composting Facilities Rwanda Environment Management Authority Republic of Rwanda Kigali, 2010.

RUGIRAMANZI, F. (2013). Landfill Sites Selection for Municipal Solid Waste Using MultiCriteria Evaluation. 9.

Saaty, T. L. (2006). Decision making - the Analytic Hierarchy and Network Processes (AHP/ANP). Journal of Systems Science and Systems Engineering, 13(1), 1-35. https://doi.org/10.1007/s11518-006-0151-5

UWINEZA, C. (2012). Municipal solid waste status in Rwanda. July.

World Bank Group. (2017). Note 4 : Profiling Secondary Cities in Rwanda - Dynamics, and Opportunities. December.

Yazdani, M., Monavari, M., Omrani, G. A., Shariat, M., \& Hosseini, M. (2015). Municipal solid waste open dumping, an implication for land degradation. Solid Earth Discussions, 7(1), 1097-1118. https://doi.org/10.5194/sed-7-1097-2015 